\title{
SUETONIUS ON THE LEGISLATION OF AUGUSTUS (AUG 34)
}

\section{David Wardle*}

\section{Introduction}

In the course of writing a detailed literary and historical commentary on Suetonius' Augustus that gives due attention to the biographer's compositional techniques while illuminating his thought and the structuring of his material, I had to pay careful attention to Augustus' short and deceptively simple chapter on legislation. This article sets out the problems of legal and historical interpretation of the biographer's words. It also proposes a possible solution to these problems, based on a broad understanding of how Suetonius assembled his material and a specific study of the moral legislation that interested him.

Suetonius' treatment of the vita publica of Augustus contains a lengthy section on the emperor's achievements in the field of law and order. ${ }^{1}$ He starts Chapter 32 with some of the major security issues facing the emperor in the mid-thirties $\mathrm{BC}$ and immediately after the civil wars. The latter part of Chapter 32 deals with various measures, most of which were contained in the lex Iulia iudiciaria, which were introduced by Augustus to improve the delivery of justice in Rome. Chapter 33 then presents a highly selective account of the emperor's own jurisdiction, which

1 The terminology chosen by JM Carter Suetonius. Divus Augustus (London, 1982) at 137.

* Professor of Classics and Deputy Dean of the Faculty of Humanities, University of Cape Town.

\section{UNISA}

Fundamina

Volume 21 | Number 1 | 2015

pp 185-204
Doi: $10.17159 / 2411-7870 / 2015 / \mathrm{v} 21 \mathrm{n} 1 \mathrm{a} 9$ Print ISSN 1021-545X/ Online ISSN 2411-7870

(c) Unisa Press 
focuses on two cases heard before his own tribunal under the process cognitio extraordinaria. ${ }^{2}$ This leads directly into the chapter at issue:

leges retractauit et quasdam ex integro sanxit, ut sumptuariam et de adulteriis et de pudicitia, de ambitu, de maritandis ordinibus. hanc cum aliquanto seuerius quam ceteras emendasset, prae tumultu recusantium perferre non potuit nisi adempta demum lenitaue parte poenarum et uacatione trienni data auctisque praemiis. sic quoque abolitionem eius publico spectaculo pertinaciter postulante equite, accitos Germanici liberos receptosque partim ad se partim in patris gremium ostentauit, manu uultuque significans ne grauarentur imitari iunenis exemplum. cumque etiam inmaturitate sponsarum et matrimoniorum crebra mutatione uim legis eludi sentiret, tempus sponsas habendi coartauit, diuortiis modum imposuit. ${ }^{3}$ (He revised laws and sponsored some from scratch, for example laws on expenditure, adultery and chastity, bribery and what orders should marry. Because he had modified the last more severely than the rest, he was not able to carry it through in the face of the disruption caused by those protesting without in the end removing or reducing part of the penalties, allowing a three-year period of grace and increasing the rewards. Despite this, when the equites persistently demanded its repeal at a public entertainment, he summoned the children of Germanicus and exhibited them, taking some of them to himself and with others on their father's lap, by his gestures and expression indicating that they should not consider it a burden to imitate the example of the young man. When he realised that the force of the law was being evaded even by betrothal with immature girls and by frequent changes of wife, he shortened the period allowed for betrothals and limited divorce.)

Good though Carter's commentary is, it tells his readers what Carter thinks they ought to know about a given subject rather than illuminates or evaluates what Suetonius says. Of the three and three-quarter pages of Carter's commentary on Chapter 34 specifically, approximately half discusses the contents of the laws to which Suetonius did not refer, as well as Augustus' intentions with regard to the field of marriage and divorce law, an important topic for anyone studying the reign of Augustus, but again not what Suetonius is interested in here. ${ }^{4}$ More recently, in an appendix to his excellent edition of Cassius Dio, Michael Swan provided a skeleton commentary on some lemmata from the chapter, which makes a useful contribution towards understanding Suetonius' version of a subject that Dio treats very differently in his essentially annalistic framework. ${ }^{5}$ In his somewhat idiosyncratic piece in the

2 R Orestano “La 'cognitio extra ordinem': una chimera” (1980) 46 Studia et Documenta Historiae et Iuris 236-247: in reality only cognitiones extraordinariae and iudicia extraordinaria existed.

3 The text is that of M Ihm C Suetoni Tranquilli de vita Caesarum (Leipzig, 1907), the standard text; the translation is my own, see D Wardle Suetonius: Life of Augustus (Oxford, 2014).

4 Other commentaries are either cursory (MA Levi C Suetoni Tranquilli. Divus Augustus (Florence, 1951) or antiquated in many details (ES Shuckburgh C Suetoni Tranquilli. Divus Augustus (Cambridge, 1896). The recent larger-scale work by $\mathrm{N}$ Louis Commentatire historique et traduction du Divus Augustus de Suétone (Brussels, 2010) has no detailed or up-to-date legal bibliography.

5 PM Swan The Augustan Succession. An Historical Commentary on Cassius Dio's Roman History Books 55-56 (Oxford, 2004) esp at 369-371. 
Aufstieg, ${ }^{6}$ Leo Ferrero Raditsa rightly highlighted the gap that had emerged by the late 1970s between scholars of Roman history and those of Roman law, making each field harder to understand. From the perspective of the early twenty-first century, the position has improved, for example through the works of Jane Gardner, Thomas McGinn and Susan Treggiari, but their approach is not the historiographical one that I pursue here. ${ }^{7}$

A feature of both Suetonius' Lives and the Historia Augusta are sections that provide résumés of imperial legislation and illuminate the different authors' competence in dealing with an important aspect of the emperor's work. ${ }^{8}$ Richard Bauman has identified two kinds of résumé, which he calls respectively "diffuse" and "concise", Chapter 34 being an example of the latter. ${ }^{9}$ Appropriately in the Augustus, given that Augustus reigned at an early time in legislative development under the Principate, the emphasis is on leges rogatae rather than senatus consulta, edicta, decreta or rescripta..$^{10}$ Bauman conjectures that Suetonius had access to a comprehensive collection of Augustan legislation in the form of commentarii kept in the imperial library, of which Suetonius was putatively librarian before becoming Hadrian's $a b$ epistulis. ${ }^{11}$ However, this hardly fits in with the general pattern of Suetonius' reading, with its excerption of annalistic histories and use of contemporary sources whose names he parades before his readers. ${ }^{12}$ What kind of material the

LF Raditsa "Augustus' legislation concerning marriage, procreation, love affairs and adultery" Aufstieg und Niedergang der Römischen Welt II 13 (Berlin, 1980) 278-339.

7 Eg, JF Gardner Family and Familia in Roman Law and Life (Oxford, 1998); TAJ McGinn Prostitution, Sexuality, and the Law in Ancient Rome (Oxford, 1998): idem "The Augustan marriage legislation and social practice: Elite endogamy versus male marrying down" in J-J Aubert \& B Sirks (eds) Roman Law as a Reflection of Social and Economic Life (Ann Arbor, 2002) 46-93; and idem "Something old, something new ... Augustan legislation and the challenge of social control" (2008) 22 Ancient History Bulletin 1-32; SM Treggiari Roman Marriage. Iusti coniuges From the Time of Cicero to the Time of Ulpian (Oxford, 1991).

8 See RA Bauman "The résumé of legislation in Suetonius" (1982) 99 Zeitschrift der SavignyStiftung für Rechtsgeschichte. Romanistische Abteilung at 81-127.

9 According to Bauman (n 8) at 84-86, Suetonius concentrates his references to leges in chapters 32 to 37, mostly treated in his "diffuse" way. Bauman conjectures (at 92-93) that the practice of résumé was known in the late Republic, although the lengthy ramblings of Dionysius of Halicarnassus on family law (2 24 7) are not a good model for Suetonius' practice; and the periocha of Livy Book 89, which postdates Suetonius, is no guide to the scale or treatment that Livy accorded Sulla's legislation. In practice, every annalistic historian who included legislation in his works will have had to précis and transform the legal material to meet the genre's requirements; the meagre fragments of the annalists do not permit us to say whether any writer from the Republic or Early Empire preceded Suetonius in treating legislation topically, rather than in its chronological place in his narrative.

10 Bauman (n 8) at 89-91.

11 For the best account of Suetonius' career, see GB Townend "The Hippo inscription and the career of Suetonius" (1961) 11 Historia 99-109.

12 See, eg, D Wardle An Historical Commentary on Suetonius' Life of Caligula (Brussels, 1994) esp at 62-63, and AF Wallace-Hadrill Suetonius (London, 1983) at 63-64, for the particular 
annalistic historians could provide on Augustus' legislation, and how they scattered it throughout their narrative, is best demonstrated by Dio.

\section{Suetonius' selection of Augustan moral legislation for discussion}

As often in Suetonius, the first word of the chapter, leges, signals to the reader a change of topic, here from imperial first- and second-instance jurisdiction to leges rogatae. When dealing with a period of dominance as long as that of Augustus, fifty-six years by Suetonius' calculation, he could discuss much legislation, comprising perhaps as many as two hundred laws. ${ }^{13}$ His opening phrase points to a clear differentiation between retractavit and ex integro sanxit. ${ }^{14}$ The former category relates to laws covering subjects on which there had already been specific legislation: for example, there were several Republican leges de ambitu; ${ }^{15}$ Sulla had initiated a lex sumptuaria, as had Caesar in $46 \mathrm{BC}$, and Sulla had probably sponsored a lex de adulteriis et de pudicitia, if Plutarch's mention of a law $\pi \varepsilon \rho \grave{i} \gamma \alpha \dot{\mu} \mu \omega \mathrm{v} \kappa \alpha i$ $\sigma \omega \varphi \rho о \sigma u ́ v \eta \varsigma^{16}$ is reliable. According to the jurist Paul, the lex Iulia de adulteriis began with an explicit abrogation of several earlier laws, ${ }^{17}$ which suggests that it could be seen as retractare, even if the control that Augustus sought to exercise, in an area that had lain mostly in the hands of patresfamiliae, was novel. The formulation quasdam ex integro sanxit indicates three things: i) these laws were not numerous, ii) they were laws on a novel subject matter, and iii) Augustus was their rogator. ${ }^{18}$ As far

exuberance of Suetonius' citations in the Augustus, displaying the biographer's expertise on the late Republic and early Empire.

13 B Biondi Scritti Giuridici vol 2 (Milan, 1965) 83 = La legislazione di Augusto (Milan, 1939). Cf Tac Ann 325 2: multitudinem infinitam ac varietatem legum.

$14 C f$ Vell Pat 289 4: leges emendatae utiliter, latae salubriter, for a similar distinction in the legislative programme of 28/27. See AJ Woodman Velleius Paterculus. The Caesarian and Augustan Narrative (Cambridge, 1983) at 255-256, who accuses Suetonius of "confusing detail", but himself causes confusion by giving retractare the same meaning as emendare. Swan (n 5) at 369 nicely translates the two verbs as "rework" and "enact".

15 On ambitus legislation, see J-L Ferrary "La législation de ambitu de Sulla à Auguste" in Iuris Vincula. Studi in onore di Mario Talamanca (Naples, 2002) 161-196.

16 Comp Lys et Sull 33.

17 Paul Coll 42 1-2. Even if this does not prove earlier legislation against adultery, but refers to stuprum, because regulations concerning stuprum and lenocinium were important elements of the lex Iulia, we are justified in considering the law as at least a partial retractatio. $C f$ G Rizzelli Lex Iulia de adulteriis. Studi sulla disciplina di adulterium, lenocinium stuprum (Lecce, 1997) at 270-271.

18 Sancire within the Life ( $c f 29$ 2, 35 3, 44 2) indicates a lex and points to Augustus' use of his tribunician power in the concilium plebis. However, Tacitus uses sancire of Augustus' role in introducing the leges Papia Poppaea (Ann 325 1: de moderanda Papia Poppaea, quam senior Augustus post Iulias rogationes ... sanxerat). In Res Gestae (8 5: legibus novi[s latis complura e]xempla maiorum exolescentia iam ex nost [ro usu reduxi) Augustus makes a noteworthy claim 
as we know, of all the laws passed during Augustus' reign, only a small proportion bore the emperor's nomen as leges Iuliae. ${ }^{19}$ Each of the laws Suetonius lists by title does seem to be a lex Iulia, an interpretation shared by the Epitomator of Aurelius Victor, whose reworking of Suetonius reads leges alias novas alias correctas protulit suo nomine. ${ }^{20}$ Whether only leges Iuliae are being discussed here is an issue of some importance for an understanding of the rest of Suetonius' passage; in particular whether any of the provisions that according to Suetonius were initiated by Augustus may stem from the lex Aelia Sentia or the lex Papia Poppaea, laws passed by the consuls of AD 4 and 9 respectively. In short, it is not possible to take a purist line on Suetonius' usual approach. For example, in his discussion on Augustus' actions concerning manumission, Suetonius attributes to Augustus the provisions of the leges Aelia Sentia and Fufia Caninia, ${ }^{21}$ so we are not justified in restricting the contents of Chapter 34 to the leges Iuliae of 18/17 BC only.

Back, however, to the introductory sentence: the $u t$ that introduces his list of laws makes it plain that Suetonius is being selective. It seems that the list contains four laws, his et de adulteriis et de pudicitia being the full title of what is generally known as the lex Iulia de adulteriis coercendis. ${ }^{22}$ If this is the case, then only the

to novae leges (see H Bellen "Novus status, novae leges. Kaiser Augustus als Gesetzgeber" in G Binder (ed) Saeculum Augustum vol 1 (Darmstadt, 1987) esp at 308-309), which certainly includes all that Suetonius places in his second category, whatever conclusion we come to on the lex de adulteriis et pudicitia (see below). Cf. eg, Sen Ben 632 1: pater legem de adulteriis tulerat; Justinian D 485 1: haec lex lata est a divo Augusto. The striking use of novae, for once nonpejorative, suggests that Augustus envisaged his legislation as an entity (see McGinn "Something old" (n 7) esp at 3-4).

19 It is impossible to be precise, given the difficulty of deciding whether to attribute particular leges Iuliae to Caesar or Augustus, but the eleven leges Iuliae of Augustus posited by G Rotondi Leges publicae populi Romani (Hildesheim, 1967) 439-462, form a reasonable core and the right order of magnitude.

20 Epit 118.

21 Aug 40 4. This is a perfectly intelligible consequence of Suetonius' biographical focus and method and does not amount to error or slackness on his part. Were our knowledge of legislation under the empire more complete, further attributions of legislative actions to his subjects by Suetonius might be linked to specific procedures ( $c f N 101$, the abolition of vectigalia).

22 In the Codex Justiniani there are two references by Domna and Proculus to a lex Iulia de pudicitia in a constitution of Severus Alexander from AD 224 (C 9 9 8-9), but the provision they cite appears to have been part of the lex Iulia de adulteriis coercendis. The paired ets, which are the only connectives in the list of laws, suggest either that Suetonius is giving the full title of the lex Iulia de adulteriis et [de?] pudicitia or that et de pudicitia is a feeble gloss on de adulteriis, perhaps reflecting a late version of the title (see Carter (n 1) at 142), of which there are several (see P Csillag The Augustan Laws on Family Relations (Bucharest, 1976) at 223 n 72). The full title is more likely, since pudicitia was a major concern of the law (cf A Mette-Dittmann, Die Ehegesetze des Augustus. Eine Untersuchung im Rahmender Gesellschaftspolitik des Princeps (Stuttgart, 1991) at 71). The suggestion of Fitzler and Seeck (Real Encyclopädie X 354) that Suetonius is referring to one compendious law is unacceptable. REA Palmer "Roman shrines of female chastity from the caste struggle to the papacy of Innocent I" (1974) 4 Rivista di Storia 
fourth law, de maritandis ordinibus, is an example of Suetonius' second category. ${ }^{23}$ All four laws can probably be dated to 18 and $17 \mathrm{BC}$ : the leges de ambitu and de maritandis ordinibus are given that date by Dio ${ }^{24}$ a possible allusion in Horace's Carmen saeculare dates the lex de adulteriis et pudicitia to before the middle of 17 $\mathrm{BC},{ }^{25}$ another allusion dates it at no later than $16 \mathrm{BC} .{ }^{26} \mathrm{It}$ is generally held that the lex de adulteriis coercendis follows logically on from the lex de maritandis ordinibus, ${ }^{27}$ so that too seems definitely to belong in 18 or $17 \mathrm{BC}$. The lex sumptuaria is the hardest to date, since we know little about its contents, but a weak case has been made out for $18 \mathrm{BC}$, on the assumption that Augustus' alleged advice to Livia on dress and adornments, extorted by an eager senate according to Dio, reflect an earlier enactment on the subject. ${ }^{28}$ The order in which the laws appear in Suetonius' list is probably not chronological, ${ }^{29}$ but determined by the distinction between retractare and ex integro sancire. Thus the first three laws belong to the first category and the lex Iulia de maritandis ordinibus to the second.

\section{The lex lulia de maritandis ordinibus}

Hanc, with which Suetonius then begins the most debated part of his discourse, one that takes up the rest of the chapter, refers only to the lex Iulia de maritandis ordinibus. Suetonius' handling of Augustus' legislation is thus highly selective, concentrating on one aspect of it. We can to some extent justify his choice because of all the new legislation, on which Augustus laid such emphasis in Res Gestae, the lex Iulia de maritandis ordinibus was the most striking in terms of what it attempted to regulate and the means by which it sought to do so. Moreover, whatever meaning we attribute to Suetonius' words, the frequency with which Augustus was compelled to return to the question of the lex Iulia de maritandis ordinibus marked it out as appropriate for particular discussion. Suetonius is not hamstrung by a need to present a flawless Augustus: indeed the Life presents examples of unacceptable behaviour not just on

Antica at 138-140 inferred a lex de pudicitia from Propertius' lex sublata (2 7 12), more plausibly related to a forerunner of the lex Iulia de maritandis ordinibus (see below), but there are no known parallels for such laws.

Swan's translation ((n 5) at 369) "he reworked the laws, enacting some afresh, for example ..." is misleading in that it subordinates sanxit rather than according it equal prominence with retractavit; for ex integro to provide the correct contrast with retractavit it must mean "from scratch", and Suetonius' examples are not all from the second group.

24 Dio 54 16 1-2.

25 57-58. See Treggiari (n 7) at 277-278.

26 Carm 45 21-24.

27 See, eg, P Girard "Les leges Iuliae iudiciorum publicorum et privatorum" (1913) 34 Zeitschrift der Savigny-Stiftung für Rechtsgeschichte. Romanistische Abteilung at $306 \mathrm{n} 1$.

28 See S Riccobono Acta Divi Augusti (Rome, 1945) at 198.

29 Contra Csillag (n 22) at 220 n 55. 
the part of the young triumvir but also on the part of the senior statesman. ${ }^{30}$ So here we need not be too surprised if the story Suetonius tells focuses more on Augustus' failure to achieve all his aims, on the ways his law was evaded and on the opposition it aroused than on its positive aspect. ${ }^{31}$

It was Paul Jörs who in 1893 first analysed most of the chapter dealing with the lex Iulia de maritandis ordinibus. He with great intelligence combined the evidence of Augustan poets with the more obvious historiographical and legal texts. ${ }^{32}$ The influence of this work on more than one hundred years of classical scholarship has been traced minutely by Tullio Spagnuolo Vigorita. ${ }^{33} \mathrm{He}$ shows that Englishspeaking scholars were hardly influenced at all by Jörs' proposed chronology and its effect on their research on the lex Iulia de maritandis ordinibus and the lex Papia Poppaea was minimal. ${ }^{34}$ This reluctance to interact with Jörs continues in the chapter by Susan Treggiari on Augustus' social legislation in the revised Cambridge Ancient History and in her important monograph on Roman marriage. ${ }^{35}$ Needless to say, none of the modern commentaries on Suetonius' Augustus enters into any debate with Jörs or recognises the consequences of his views for the study of Suetonius. Richard Bauman's brief discussion of Chapter 34 disagrees in every respect with Jörs and fails to mention him, ${ }^{36}$ while Michael Swan, whose commentary on Cassius Dio does engage fully with Jörs, denies that Suetonius makes any reference to Augustan marriage legislation of later than 18 BC. I shall attempt to present Jörs' arguments and evaluate them through a close examination of Suetonius and Dio, in the process clarifying Suetonius' references at each stage. The table that follows this article presents a synoptic view of the positions taken by Jörs, Bauman, Swan and myself on each element of Suetonius' argument.

30 See, eg, 27 4, 691.

31 I leave only to those who like to resort to psychology, the idea that the biographer whose marriage had proved childless (Plin Ep 1094 2) and had to receive from Trajan a special grant of ius trium liberorum (Plin Ep 10 95) enjoyed highlighting the difficulties encountered by Augustus in pursuing his matrimonial legislation. In Augustus (eg, 35 1 54) Suetonius frequently mentions the obstructions faced by Augustus.

32 P Jörs "Die Ehegeschichte des Augustus" in Festschrift für Theodor Mommsen zum fünfzigjährigen Doctorjübilaum (Marburg, 1893) re-issued with lengthy introduction by T Spagnuolo Vigorita Iuliae rogationes. Due studi sulla legislazione matrimoniale augustea (Milan, 1985), a collection which also includes Jörs' doctoral thesis Über das Verhältnis der lex Iulia de maritandis ordinibus zur Lex Papia Poppaea (Bonn, 1882).

33 T Spagnuolo-Vigorita Casta domus. Un seminario sulla legislazione matrimoniale angustea ${ }^{3}$ (Naples, 2010). The first edition was published in 1985.

34 The exception is T Rice Holmes The Architect of the Roman Empire 27 BC-AD 14 (Oxford, 1931) at 151-152, who follows Jörs fully on the putative law of AD 4.

35 (n 5) eg, at 60-61.

36 (n 8) at 84-85. 


\section{Jörs' argument in favour of three stages of legislation}

Jörs rightly asserts that Suetonius describes three stages of legislation, which he identifies as i) the lex Iulia de maritandis ordinibus, ii) a drastic revision of the lex Iulia de maritandis that Augustus failed to sustain, and iii) a less harsh form of the revision with smaller penalties, higher rewards and a three-year exemption, a measure that was successfully implemented. ${ }^{37}$ By using Dio's extensive account of

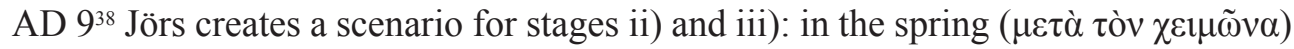
Tiberius returned to celebrate his successes over the Pannonians, but at the victory celebrations put on by the consuls the equites demonstrated, demanding the repeal of the law concerning the unmarried and the childless. ${ }^{39}$ Augustus responded to this by summoning the equites to the forum and addressing them in two groups, separating the minority who were married from the majority who were not. In the course of Dio's version of the address to the latter group Augustus, emphasising his own restrained and generous treatment of the equites, mentions two separate periods, totalling five years, during which his marriage regulations had not been implemented. ${ }^{40}$ According to Jörs, the equites demonstrated when this period of grace (vacatio) came to an end, thus indicating a law passed in AD $4 .{ }^{41}$ Augustus' response to the protest is set out in the immediate continuation of Dio's narrative: 42

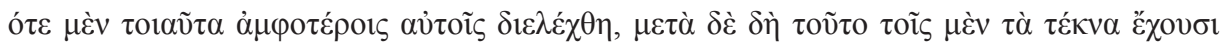

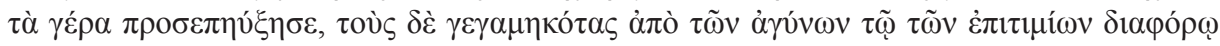

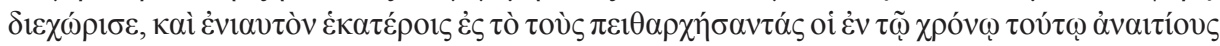

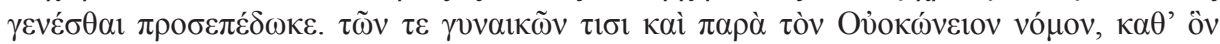

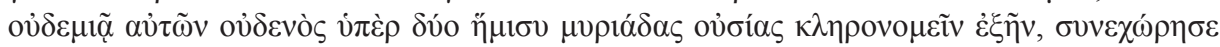

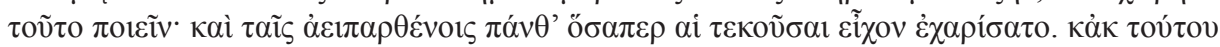

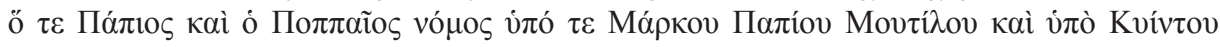

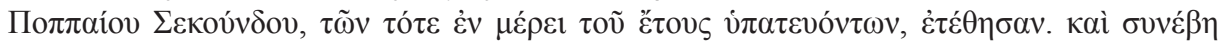

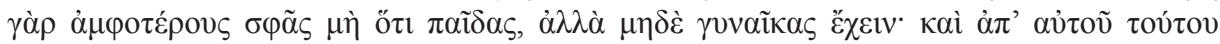

37 Jörs (n 32) at 49-51.

38 For the enlarged scale and survival of most of the original, see Swan (n 5) at 223.

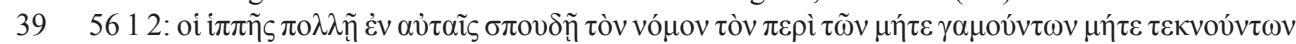

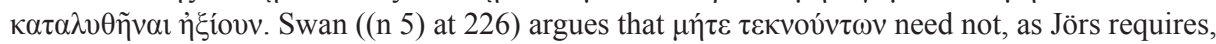
refer to orbi, but to caelibes, who as a consequence of not being married do not have (legitimate) children, as Augustus mentions in his speech.

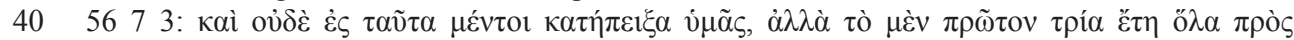

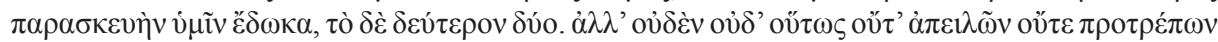

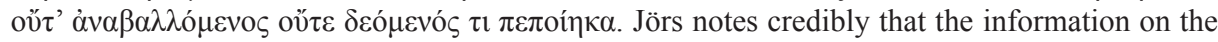
two vacationes could not have been invented and that arguments attributed to Augustus on the danger posed by emancipations and foreigners were consistent with his reign and not with Dio's own time.

41 Spagnuolo Vigorita ((n 33) at 74-75) believably identifies this law as a lex Aelia Sentia separate from that de manumissionibus, passed in the first half of $\mathrm{AD} 4$, verified directly only by a papyrus from AD 138 (PMich 7 438). $56101-3$. 


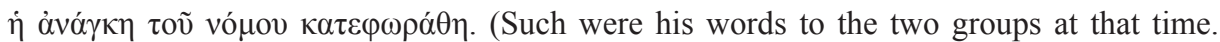
Afterwards he increased the rewards to those who had children and in the case of the others drew a distinction between married men and unmarried ones by imposing different penalties; furthermore, he granted yet another year's grace to those who were remiss in either respect, in which to obey him and thus escape the penalties. Contrary to the lex Voconia, according to which no woman could inherit property to the value of more than one hundred thousand sesterces, he permitted some women to inherit larger amounts; and he granted the Vestal Virgins all the privileges enjoyed by women who had borne children. And thus was enacted the lex Papia Poppaea by Marcus Papius Mutilus and by Quintus Poppaeus Secundus, who were consuls at the time for a part of the year. Now it chanced that both of them were not only childless but were not even married, and from this very circumstance, the need for the law was apparent.)

Augustus outlined a series of proposals that were then enshrined in the lex Papia Poppaea, introduced by the suffect consuls in the second half of the year: i) increased rewards for those who had produced children; ii) a distinction to be drawn between the penalties imposed on the married who were childless and those who were unmarried; ${ }^{43}$ iii) a further period of grace (vacatio) of one year for both groups before the provisions of the law came into effect; iv) the exoneration of women from the lex Voconia, which had restricted their rights to inherit and make wills; and v) the Vestal Virgins to be granted the privileges secured by women in terms of the ius trium liberorum. So Jörs' most important contribution is to have posited a law passed in AD 4 that increased the severity of the terms of the lex Iulia de maritandis ordinibus, so much so that Augustus was forced to make a series of concessions, which were incorporated in the lex Papia Poppaea. Because Dio's narrative for AD 4 is very abridged, there is no trace of the legislation in it, but every reference in Book 56 to earlier legislation is consistent with such a law.

Ostensibly greater difficulties arise when Jörs applies the framework that he has extracted from Dio's chronological work to Suetonius. He rightly asserts that two cums, hanc cum ... emendasset and cumque etiam ... sentiret, provide the basic structure for Suetonius' discussion: the law that people tried to evade by extended betrothals and serial divorces was identical with hanc, namely the lex de maritandis ordinibus, for which he found confirmation in words from Dio's account of 18

43 According to Jörs ((n 32) at 55-57) this is the crucial piece of evidence: he argues that in our existing legal texts, punishment for the orbi, that is for the married men who had no children, is associated only with the lex Papia Poppaea (eg, Gaius 2 111, 286), not with the lex Iulia de maritandis ordinibus, so that the equites' protest against the punishment of orbi must refer to a law that predates the lex Papia Poppaea and which introduced a harsher penalty than the known prescription of the lex Papia Poppaea: caelebs nihil, orbus dimidium capit. 
$\mathrm{BC}$ suggesting the same evasion. ${ }^{44}$ The demonstration by the equites interrupts the logical flow of the argument. ${ }^{45}$

\section{Evaluating Jörs' approach}

I propose to consider, through a phrase-by-phrase discussion of Suetonius' account, whether it is Jörs' or alternative approaches that make best use of the literary, legal and historiographical evidence available and how that affects our view of the biographer.

Although the reference of hanc to the lex Iulia de maritandis ordinibus as enacted in $18 \mathrm{BC}$ is undisputed, the meaning of the rest of the clause cum aliquanto severius quam ceteras emendasset and its relationship to the enacted law is wide open to dispute. Jörs has no problem in finding here a reference to a harsher law, but he rightly realises that, once the cum clause looks forward to legislation postdating the enacted lex Iulia de maritandis ordinibus, then quam ceteras becomes problematic, because there is no known reworking by Augustus of any of the laws in Suetonius' list other than the lex de ambitu. ${ }^{46} \mathrm{He}$ therefore considers that these words may be understood as quam ceterae latae erant or even be relegated to being a gloss on severius. Both these suggestions seem to me to be problematic. Rather, the reference may be taken as looking backwards in one of two ways. If Suetonius is saying that Augustus' proposed changes to republican practice in relation to what would become the lex Iulia de maritandis ordinibus were harsher than those in relation to ambitus, luxury or even sexual misconduct, then the difficulty disappears. Most scholars would agree that the lex Iulia de maritandis ordinibus affected more people, particularly the elite, more severely than, for example, the lex Iulia de adulteriis coercendis. ${ }^{47}$ Alternatively, as Bauman and Swan do, we can take this to mean that Augustus circulated a draft text of the lex Iulia de maritandis ordinibus (and his

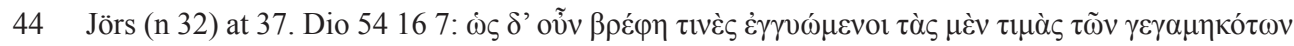

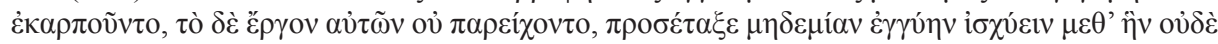

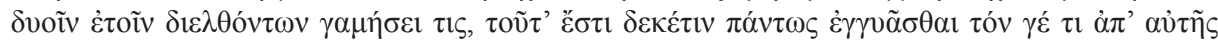
$\dot{\alpha} \pi \mathrm{o} \lambda \alpha \tilde{\sigma} \sigma \mathrm{ov} \tau \alpha$.

45 Bauman ((n 8) at 85: "irrelevant part") also acknowledges that the demonstration is inserted awkwardly by Suetonius.

46 (n 32) at 49-50; $c f$ Csillag (n 22) at 33. With reference to 8 BC Dio (55 5 3) narrates changes to electoral practice that may plausibly be connected with heightened measures against ambitus. He does not, however, indicate if the measures of 8 involved a law. Tacitus' plural "ambitus Iuliae leges" (Ann 15203 ) is not conclusive. Jörs sees in the vague reference of Aulus Gellius to an edict of either Augustus or Tiberius recorded by Ateius Capito (2 24 14: esse etiam dicit Capito Ateius edictum - diuini Augusti an Tiberii Caesaris non satis commemini-, quo edicto per dierum uarias sollemnitates a trecentis sestertiis adusque duo sestertia sumptus cenarum propagatus est, ut his saltem finibus luxuriae efferuescentis aestus coerceretur) a later exacerbation of the lex Iulia sumptuaria, but Gellius makes it clear that this edict was a loosening of the restrictions of the lex, not "eine Verschärfung".

47 See PA Brunt Italian Manpower (Oxford, 1971) at 560. 
other laws) in $18 \mathrm{BC}$ in order to elicit comment. ${ }^{48}$ Dio mentions with reference to $27 \mathrm{BC}$ but in a general context, that public comment was elicited regularly. ${ }^{49} \mathrm{John}$ Rich limits the consultation process to senators, positing that the senatorial advisory committee, Augustus' consilium, was initially set up to aid the formulation of the moral legislation. ${ }^{50}$ Rich's exclusion of other input is unfounded, unless the equites' demonstration in AD 9 at ludi is taken as evidence that they had no other way of influencing legislation, rather than that such public demonstrations were highly

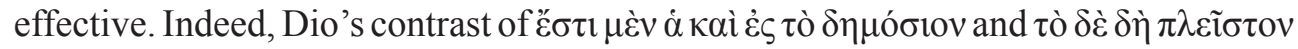
... would seem to exclude Rich's interpretation. Moreover, Augustus' publication by edict of the speech by Q Caecilius Metellus Macedonicus de prole augenda ${ }^{51}$ in the context of the lex Iulia of 18 BC, if its appearance there in Livy's summary is reliable, ${ }^{52}$ demonstrates wide promulgation of Augustus' justifications and, by easy extension, of the proposed measures themselves. Seen in this light emendasset can retain its regular sense of revise..$^{53}$ So far, then, the balance of difficulties probably lies against Jörs' understanding of cum ... emendasset, although his construction does enable us to see that orbi, whose capacitas to inherit was not affected under the lex Iulia de maritandis of $18 \mathrm{BC}$, were treated more harshly later. ${ }^{54}$

48 Jörs ((n 32) at 50 n 3) rules out any idea that Augustus had treated any of the material of the lex de ambitu or sumptuaria earlier. If Jörs means actual legislation, then as long as we cannot analyse the general statement by Velleius Paterculus (2 89 3) his assertion cannot be disproved. See Bauman (n 8) at 84, Swan (n 5) at 370.

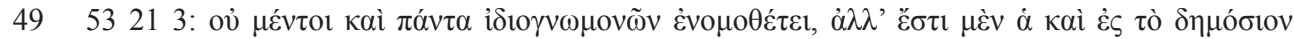

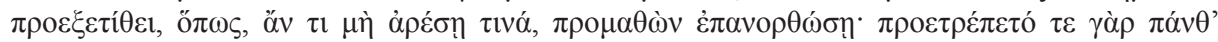

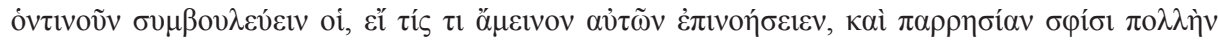

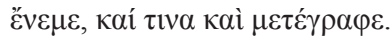

50 JW Rich Cassius Dio: The Augustan Settlement (Warminster, 1990) at 154.

51 Aug 89 2: populo ... per edictum saepe fecit.

52 Livy Per 59.

53 The only other use of emendare in Suetonius is a reference to Domitian sending agents to Alexandria to transcribe and emendare manuscripts in Alexandria (Dom 20 1), which is not the sense required here. Thesaurus Linguae Latinae V $46124-41$ provides few useful parallels of emendare used with lex, notably Tert Apol 4 6: errare in lege condenda ... Lycurgi leges emendatae; Claudian 8 505-6: priscamque resumunt / canitiem leges, emendantur vetustate / acceduntque novae; CJ 651 1 1: lex Papia ab anterioribus principibus emendata fuit et per desuetudinem abolita. Here the main sense seems to be "revise", in the sense of "bring up to date", to suit a new situation. Swan ((n 5) at 370) insists that emendasset should be translated as "reform" rather than "amend", whereas Brunt ((n 47) at 559 n 1) notes: "I take this to mean that in Suetonius' view Augustus' law was an 'amendment' of earlier enactments." For its broader use in the Digest, see E Grupe Vocabularium iurisprudentiae Romanae vol 2 (Berlin, 1933) at 468-469, and in the Codex Justiniani, see R Mayr Vocabularium Codicis Iustiniani (Hildesheim, 1965) at 921-922.

54 See Swan (n 5) at 231. Dio confirms the legal texts. 


\section{Does Suetonius refer to legislation before 18/17 BC?}

We have next to deal with hanc ... prae tumultu recusantium perferre non potuit nisi adempta demum lenitive partium poenarum ... . Bauman leaves open the possibility that the opposition expressed by Suetonius was to a piece of legislation known only from Propertius' elegies: gavisa est certe sublatam, Cynthia, legem / qua quondam edicta flemus uterque diu / ni nos divideret. ${ }^{55}$ The date, nature and legal status of this measure have been the subject of prolonged debate: whether it belonged to the triumviral period or to the laws enacted by Augustus between 28 and $26 \mathrm{BC}$ at the beginning of his principate proper; whether the measure was primarily financial or sought to regulate the right to marriage of free-born Romans, and whether the measure was a law that was fully enacted (lex), and then abrogated, or a bill that was merely promulgated (rogatio) but not passed. The key to the debate is the precise meaning of Propertius' lex and edicta: Badian, perhaps the most influential discussant of the passage in the English-speaking world, argued that Propertius was referring to a triumviral decision with the force of law that imposed financial penalties on the unmarried and that the expression lex sublata never refers to a withdrawn rogatio. ${ }^{56}$ However, in non-legal texts the use of lex for rogatio is unexceptional and Caesar provides a pertinent example in which sublata priore lege means a bill withdrawn in the face of opposition. ${ }^{57}$ Although Augustus was prevented from passing this law, he succeeded in transferring some of the clauses of his intended legislation into other measures that were passed in $27 \mathrm{BC}$ : for example, career priority for those who were married and had children was enshrined in the lex annalis and/or the lex de provinciis of $27 \mathrm{BC} .{ }^{58}$ Although the historicity of this earlier Augustan rogatio now seems beyond dispute, is this the rogatio that Suetonius refers to in perferre non potuit?

If that identification is to be accepted, the events of c $27 \mathrm{BC}$ and those of 18/17 $\mathrm{BC}$ must in effect be seen as a single piece of legislative activity spread over a long period. The only clue to the duration of the process is demum. Unfortunately, Suetonius' usage is so varied as to provide certainty only in respect of the chronological sequence of events discussed..$^{59}$ Jörs himself takes demum to indicate a lengthy period, which he identifies as that between AD 4, when he believes Augustus enacted his

55 (n 8) at 84. Propertius $2711-12$.

56 E Badian “A phantom marriage law” (1985) 129 Philologus 82-98.

57 Caes BCiv 321 1. See P Moreau, "Florent sub Caesare leges. Quelques remarques de technique legislative à propos des lois matrimoniales d'Auguste" (2003) 81 Revue Historique de Droit Français et Étranger at 461-467.

58 See Moreau (n 57) at 468-469.

59 Suetonius uses demum frequently (x 33) and sometimes with reference to a short period, eg $A u g$ 104 of two days. Where there are no other chronological indications the periods in question, where they can be ascertained, may range from a few days (Tib 51 2, Cal 9) to a few months (N2 3 ) or even to a year or more (Iul 23 1, Ve 2 2). Suetonius' other use of demum, simply to place events in a sequence may be most relevant here (Tib 61 1, Cal 38 3, Cl 5 1). 
severe law, and AD 9, when the lex Papia Poppaea was enacted. However, the only protest against the putative law of AD 4 that resulted in changes took place five years after the passing of the said law, which is not the sequence that Suetonius envisages. Moreover, perferre naturally means "carry [into law]" and Suetonius must be taken to mean that the measure was not "carried into law" in the form Augustus wanted. ${ }^{60}$ The most likely time when a relatio was withdrawn is the period leading up to the enactment of the lex Iulia de maritandis ordinibus, the nineteen months between Augustus' return to Italy in October $19 \mathrm{BC}$ and May $17 \mathrm{BC} .{ }^{61}$ This identification provides us with a context in which Augustus himself presented a rogatio, withdrew it in its original form, but persisted and passed a lex that bore his name (like the other laws explicitly mentioned by Suetonius), although it was not as severe as he had originally intended.

\section{Dating Augustus' concessions}

Nisi adempta demum lenitive partium poenarum et vacatione trienni data auctisque praemiis according to Jörs refers to the concessions that were incorporated into the lex Papia Poppaea, for the alternative view they were incorporated in the lex Iulia de maritandis ordinibus. In attempting to evaluate the differing arguments, we face two problems, firstly that Suetonius provides us with insufficient detail on the first and third concessions to enable us to know what he means, and secondly, the equally insurmountable problem that the legal sources providing the bulk of the detailed information on the lex Iulia de maritandis ordinibus (whether we take this as the law of $18 \mathrm{BC}$ or that of AD 4) and the lex Papia Poppaea for the most part treat them as one law. ${ }^{62}$ Likewise, to determine what might have been in the draft version of the lex

60 For Jörs it cannot mean "carry into law", because it is fundamental to his case that there was a lex (vó $\mathrm{os}_{\text {) }}$ in $\mathrm{AD} 4$. It must therefore have a non-technical sense of, for example, "see through to completion" ((n 32) at 50: "Sueton spricht von einem zweiten, die lex de maritandis ordinibus verschärfenden Gesetz, und von diesem sagt er, Augustus habe es nicht durchbringen können"). Of the eight other uses of perferre in Suetonius none has even a vaguely legal sense (see AA Howard \& CN Jackson Index Suetonianus (Cambridge Mass, 1922), so Jörs' view cannot be excluded on linguistic grounds, but remains improbable.

61 The termini are fixed: Augustus' return was commemorated formally on 12 Oct 19 BC (Fast Amit); a senatorial decree of 23 May 17 BC contains an explicit mention of the lex Iulia de maritandis ordinibus (CIL 632323 ll 57ff: qui lege de marita< andis ordinibus tenentur $>$ ).

62 Eg, Bauman (n 8) 85 n 9; Carter (n 1) at 143; Mette-Dittmann (n 22) at 162-165; and above all R Astolfi La lex Iulia et Papia 4 (Milan, 1996) esp at 15. Although Spagnuolo Vigorita ((n 32) at xviii-xix) rightly emphasises Jörs' achievement in his doctorate in differentiating the two laws, there are still large gaps in our knowledge. For a handy summary of the various ways the relationship between the two laws can be set out, see AM Kemezis "Augustus the ironic paradigm: Cassius Dio's portrayal of the lex Julia and lex Papia Poppaea" (2007) 61 Phoenix 274 n 14. 
Iulia de maritandis ordinibus we would need to work backwards from the provisions of the enacted law.

Key provisions involving restrictions and penalties in the laws were: i) unmarried men aged between twenty-five and sixty and unmarried women between twenty and fifty could not receive inheritances outside the sixth degree of their agnatic family; ii) a disbarred heir had one hundred days in which to acquire a spouse; iii) divorcees within the age limits had six months, and widows a year, in which to remarry under the lex Iulia de maritandis ordinibus and twice as long under the lex Papia Poppaea; and iv) one surviving child exempted a man from the limitations of the law, and three surviving children exempted a woman. In theory the provisions relating to any of these four topics may have been more severe in the previous version of the legislation required by each view, but it is only in respect of the third provision that we know this was so.

The second specific concession, Suetonius' vacatio trienni, was linked by Jacques Cujas with Ulpian's testimony concerning the time within which the lex Papia Poppaea allowed a woman to remarry after the death of her husband ${ }^{63}$ His interpretation has been influential, as befits one of the greatest renaissance scholars, but requires an unnecessary emendation of Ulpian ${ }^{64}$ and takes us too far from the original lex Iulia, whose provisions concerning the period allowed for remarriage are known to have been stricter than those of the lex Papia Poppaea. Rather this vacatio is a three-year moratorium, or period of grace before the provisions of the lex came into effect, a sufficient period for not only marriages but also the birth of children, in order to free couples and individuals from the law's restrictions. Jörs connects this with the three-year vacatio that Augustus in AD 9 claimed he had granted after the passing of an earlier law, that of $\mathrm{AD} 4 .{ }^{65}$ The other view connects the vacatio with the lex Iulia de maritandis ordinibus of $18 \mathrm{BC} \cdot{ }^{66}$ Here it seems that Jörs has a stronger case, because the acta of the Ludi Saeculares contain a senatus consultum passed in May $17 \mathrm{BC}$, permitting those banned in terms of the lex de maritandis ordinibus to attend the Ludi Saeculares. ${ }^{67}$ If a three-year vacatio had been incorporated in the law, as Suetonius' text would suggest, then there would have been no need for the Senate

63 J Cujas Opera omnia vol 1 (Turin, 1758) at 319; Tituli Ulpiani 14: lex autem Papia a morte viri biennii [tribuit vacationem]. The notion is still held by Treggiari ((n 5) at 73-74) and MetteDittmann ((n 22) at 132). Rich ((n 50) at 193) understands three years as the maximum length of an engagement.

64 Astolfi (n 62) at $84 \mathrm{n}$ 59. For the standing of Cujas, see, eg, DR Kelley Foundations of Modern Historical Scholarship: Language, Law, and History in the French Renaissance (New York, 1970) at 112-115.

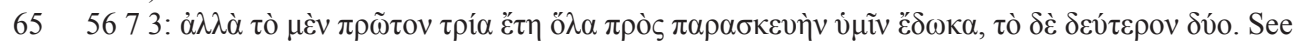
(n 32) at 57-58.

66 See Real Encyclopädie X 345; Carter (n 1) at 144; Swan (n 5) at 230-231.

67 CIL 632323 157: magistri s(acris) f(aciundis) [ed]ent, s(ine) f(raude) s(ua) spectare liceat ieis qui lege de marita[andis ordinibus tenentur]. 
to pass a decree. ${ }^{68}$ Moreover, all that Dio can find in the draft lex Papia Poppaea is a vacatio of one year. ${ }^{69}$ To validate Suetonius' testimony, we would need to posit that either the actual lex Papia Poppaea contained a vacatio of three years or that Augustus subsequently authorised one. ${ }^{70}$

Suetonius discusses the third concession, relating to increased rewards, too briefly to allow us to reach any definite conclusion. The range of praemia available under the lex Papia Poppaea for the married who produced children was substantial: seniority in collegial offices for the married man with more children; advancement in relation to the leges annales for magistracies; exemption from the duty of guardianship or curatorship; the right of husband and wife to inherit from each other, and more than $25 \%$ of the amount secured by the aerarium for those who initiated prosecutions under the law. ${ }^{71}$ Of these praemia, only the right of spouses to inherit from each other was probably extended in the lex Papia Poppaea and the financial benefits for delatores introduced. ${ }^{72}$

\section{Identifying and dating the protest by the equestrian order}

The next issue is the major demonstration by the equites: $:^{73}$ Do Suetonius and Dio describe different protests and what their likely context is? If, as Swan appears to

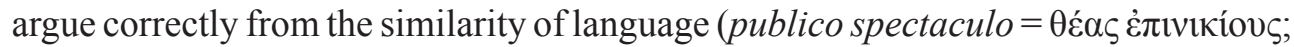

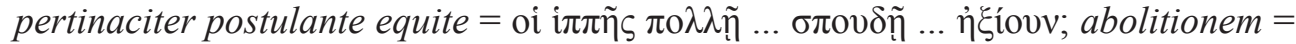
$\kappa \alpha \tau \alpha \lambda \nu \theta \tilde{\eta} v \alpha \mathrm{l})$, Suetonius and Dio refer to the same protest by the equites, this incident

68 Swan ((n 5) at 370) argues that not all the law's provisions were subject to the moratorium. It would be surprising if the major penalties of the law were suspended, such as the restriction on inheritance, while minor penalties were left intact.

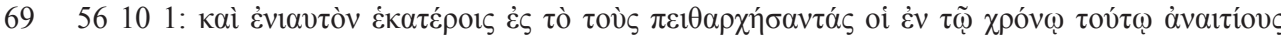
$\gamma \varepsilon v \varepsilon \dot{\sigma} \theta \alpha 1 \pi \rho \circ \sigma \varepsilon \pi \varepsilon \dot{\delta} \omega \kappa \varepsilon$.

70 Such a notice could have appeared in the lacuna in the narrative or in relation to urban affairs in AD 9 and 10. Certainly no reference to a vacatio survives in the epitomised versions, but they also omit any mention of the one recorded by Dio at 56101 .

71 Treggiari (n 5) at 66-75.

72 Contra Carter (n 1) at 144. Priority in the consular fasces, attributed by Gellius (2 15 4) to the lex Iulia and Ulpian (Vat fr 197) generally confirms that priority in magisterial fasces was covered by the lex Iulia de maritandis ordinibus; advancement in terms of the leges annales was legibus cavetur according to Ulpian, hence also covered by the lex Iulia; immunity from tutela for free women with three children goes back to 18 BC (Gaius 1 145), but for freedwomen with four children only to AD 9 (Gaius 3 44; Ulp 29 3); freedmen were exempted from the operae to their patronus in $18 \mathrm{BC}$ if they had two children; the married woman who produced the requisite number of children could wear the toga instita from $18 \mathrm{BC}$.

73 Spagnuolo Vigorita ((n 33) at 106) wrongly understands Suetonius' singular eques to refer to an individual protestor, but where the biographer uses the singular without an accompanying adjective Romanus it refers unequivocally to the order of equites (often in contrast with the Senate) (cf Cal 26 4, N 11 1, 12 3, Ve 9 2, Dom 4 5, 83 ). 
is linked by the clear chronological detail in Dio to the victory parades in honour of Tiberius' Pannonian success. This was celebrated in spring AD 9, before the passing of the lex Papia Poppaea at some time during the second half of the year when M Papius Mutilus and Q Poppaeus Secundus were suffect consuls. According to Jörs and Spagnuolo Vigorita, Suetonius had the equites protesting against the lex Papia Poppaea itself, even though it embodied concessions. Thus the biographer describes a later, different demonstration from the one referred to by Dio, who cannot be held to have dated his demonstration incorrectly. ${ }^{74}$ According to Spagnuolo Vigorita, the demonstration took place during the one-year vacatio granted after the passing of the lex Papia Poppaea in the first half of AD $10 .{ }^{75}$ Suetonius' testimony that Germanicus had many children suggests a date some time in AD 9. ${ }^{76}$ Thus Augustus would have been able to refer to Germanicus as a perfect example, since Germanicus' marriage to Agrippina probably took place in $\mathrm{AD} 4$ or in $\mathrm{AD} 5$ at the latest, and was splendidly fertile. Jörs' argument that Germanicus did not return to Rome in time for the spring games depends solely on Dio's statement that Germanicus announced the final Tiberian victory over Dalmatia in late summer or early autumn, just before news of the Varus disaster reached Rome, but his presence in Rome earlier in the year is not excluded. ${ }^{77}$ Suetonius' opening two words sic quoque may indicate where he believed the protests to have taken place. Swan argues convincingly that they must mean "despite this" or "even so", namely despite the concessions. ${ }^{78}$ If, according to Swan, the concessions were included in the lex Iulia de maritandis ordinibus of $18 \mathrm{BC}$, Suetonius' reference to a demonstration, which he knew occurred in AD 9, to illustrate opposition to it, involves his "overlook[ing] the chronological leap", ${ }^{79}$ and thus the demonstration becomes chronologically separate from the material on both sides of it. In Swan's view, Suetonius' treatment of Augustan legislation on marriage stops in $18 \mathrm{BC}$, and the law that features most prominently in the literary

74 (n 32) 52. So also S Demougin L'ordre Equestre sous les Julio-Claudiens (Rome, 1988) 573.

75 (n 33) 64-66, 77.

76 At this stage Germanicus had at least two children: his sons Nero and Drusus were born in AD 6 and 8 at the latest. Unless partim ... partim is rhetorical exaggeration for just two children, another child may well be indicated. Agrippina bore their sixth child Caligula in Aug AD 12; of the intervening three, the third and fourth children died infantes and the fifth Gaius survived a little longer ( $\mathrm{Cal} 7$ ). Only the third is likely to have been alive in spring AD 9, the baby Tiberius (CIL 6 888). See T Mommsen "Die Familie des Germanicus" (1878) 13 Hermes at 247-248; JW Humphrey "The three daughters of Agrippina Maior" (1979) 4 American J of Ancient History at 137 n 12; and H Lindsay "A fertile marriage: Agrippina and the chronology of her children by Germanicus" (1995) 54 Latomus at 6. Spagnuolo Vigorita ((n 33) at 61) conjectures that there may have been four living sons in the first half of $\mathrm{AD} 10$, but the expression may also relate to just three sons.

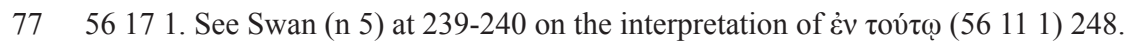

78 His paraphrase "even though the law was mitigated in this way, the equites ..."; cf Jörs (n 32) at 51: "trotz der Milderungen". In addition to the parallels cited by Swan (Aug 78 2, Tib 652 and Cl 24 1); see Iul 70.

79 (n 5) at 370. 
and legal sources, the lex Papia Poppaea, is totally ignored. If, however, the final two parts of Suetonius' discussion refer to the lex Papia Poppaea (or the lex Aelia Sentia), then the equites' demonstration is not isolated in the context of the rest of the chapter: Augustus is portrayed as responding actively and logically to the abuse of his legislation and firmly ignoring protest.

\section{Augustus' final measures}

Do the measures that Suetonius attributes to Augustus accord with what we know of the lex Papia Poppaea? Firstly, Suetonius says that when Augustus realised that men were evading the provisions of the law by entering into betrothals with immature girls, he reduced the period allowed for betrothals (tempus ... sponsas habendi coartavit). Dio's treatment of the topic appears inconsistent: for $18 \mathrm{BC}$ he records an order that restricted betrothals to no more than two years and concludes that the minimum age for girls at betrothal was ten; ${ }^{80}$ but in the speech he attributes to Augustus in AD 9, Augustus says that he has done nothing to prevent the betrothal of girls too young for marriage. ${ }^{81}$ Treggiari argues that there was no restriction before the lex Papia Poppaea; Astolfi and Mette-Dittmann assert credibly that changes to the lex Iulia were included in the lex Papia Poppaea. ${ }^{82}$ The latter law certainly set at two years the maximum length of a betrothal that would enable the parties to count as married, which entailed that the minimum age for a fiancée who helped the man evade the penalties of the law became ten years..$^{83}$

Secondly, Augustus imposed some limitation on divorce (divortiis modum imposuit). This cannot refer to the number of divorces any man might initiate: "there is no evidence or likelihood that Augustus could restrict freedom to divorce", indeed Seneca complains about frequent and trivial divorces and Martial jokes about the frequent marriages of Telesilla. ${ }^{84}$ It is likely that the regulations were tightened up in some way, although it is impossible to know what restrictions were introduced, given the brevity of Suetonius' comment and the absence of any relevant information in the legal sources. Some sources suggest that what is meant is that seven witnesses were needed for a divorce, which would have been a new form of divorce procedure..$^{85}$ Other sources refer to a restriction on freedwomen who wanted to divorce their patrons (surely a rare occurrence) ${ }^{86}$ or measures concerning the dowry, for example

$80 \quad$ Dio 54167.

81 Dio 5672.

82 Treggiari (n 5) at 65; R Astolfi ("Il fidanzamento nella lex Iulia et Papia" in Studi in onore di Eduardo Volterra vol 3 (Milan, 1971) esp at 682-685; Mette-Dittmann (n 22) at 163-164.

83 If the testimony of post-classical jurists is relevant, the absolute minimum age for betrothals was seven (D 231 14).

84 Treggiari (n 5) at 453; Sen Ben 3 16 2-4; Martial 67.

85 Jörs (n 32) at 38; Astolfi (n 62) at 194.

86 Eg, E Levy Der Hergang der römischen Ehescheidung (Weimar, 1925) at 49-51. 
permitting the husband to retain a part of the dowry when either the wife or her paterfamilias initiated the divorce, ${ }^{87}$ or reducing the time allowed to the ex-husband to repay the dowry when he had initiated the divorce, ${ }^{88}$ or limiting the time stipulated before a divorced woman had to remarry or lose the privileges of the married. ${ }^{89}$

\section{Conclusion}

If this examination of Suetonius' treatment of a key element of Augustus' social legislation has accurately identified the stages and measures that the biographer discussed, then it appears that Suetonius did not focus only on the legislation of 18/17 BC, but, appropriately, demonstrated Augustus' concerns and activities up to AD 9, when the lex Papia Poppaea was passed. If this is so then Suetonius' understanding of the provisions of the latter as a tightening up of the lex Iulia resembles that of Tacitus, who in a famously cynical survey saw the lex Papia Poppaea as a pernicious law that gave free rein to delatores and plunged all into terror. ${ }^{90}$ The biographer, however, lets no shadow fall on Augustus - there are no comments on the continuing ineffectiveness of the marriage legislation. Rather he depicts the paradigmatic emperor as persisting in upholding traditional morality and above all the institution of marriage, although the weakness of others forced him to be less strict than he would have wished. Suetonius depicted Augustus as remaining resolute, citing examples of good moral conduct that could be followed and closing loopholes when he saw his own legislation being circumvented.

\begin{tabular}{|l|l|l|l|l|}
\hline Suetonius & $\begin{array}{l}\text { Jörs/Spagnuolo } \\
\text { Vigorita }\end{array}$ & Bauman & Swan & Wardle \\
\hline $\begin{array}{l}\text { hanc ... } \\
\text { prae tumultu } \\
\text { recusantium } \\
\text { perferre non potuit }\end{array}$ & $\begin{array}{l}\text { successor to } \\
\text { LIMO (lex lulia } \\
\text { de maritandis } \\
\text { ordinibus) of } \\
18 / 17 \mathrm{BC}\end{array}$ & $\begin{array}{l}\text { Final version } \\
\text { of } L I M O \text { or } \\
\text { the Propertian } \\
\text { legislation }\end{array}$ & $\begin{array}{l}\text { Final version } \\
\text { of } L I M O \text { of } \\
18 / 17 \mathrm{BC}\end{array}$ & $\begin{array}{l}\text { Final version } \\
\text { of } L I M O \text { of } \\
18 / 17 \mathrm{BC}\end{array}$ \\
\hline $\begin{array}{l}\text { cum aliquanto } \\
\text { seuerius } \\
\text { quam ceteras } \\
\text { emendasset }\end{array}$ & $\begin{array}{l}\text { A putative lex of } \\
\text { AD } 4\end{array}$ & $\begin{array}{l}\text { Draft version } \\
\text { of } L I M O \text { of } \\
18 / 17 \mathrm{BC}\end{array}$ & $\begin{array}{l}\text { Draft version } \\
\text { of } L I M O \text { of } \\
18 / 17 \mathrm{BC}\end{array}$ & $\begin{array}{l}\text { Draft version } \\
\text { of } L I M O \text { of } \\
18 / 17 \mathrm{BC}\end{array}$ \\
\hline
\end{tabular}

87 See M Humbert Le remariage à Rome (Milan, 1972) at 136-137.

88 A Söllner Zur Vorgeschichte und Funktion der actio rei uxoriae (Cologne, 1969) at 117.

89 Treggiari (n 5) at 454.

90 See Ann 325 1. That Suetonius included among the creditable works of Nero ( $N 101)$ a reduction in the rewards payable to delatores under the lex Papia Poppaea may suggest a degree of coolness towards that aspect of the law, but no criticism can be discerned in the Augustus. 
SUETONIUS ON THE LEGISLATION OF AUGUSTUS

\begin{tabular}{|c|c|c|c|c|}
\hline $\begin{array}{l}\text { nisi adempta } \\
\text { demum lenitaue } \\
\text { parte poenarum }\end{array}$ & $\begin{array}{l}\text { lex Papia } \\
\text { Poppaea }\end{array}$ & $\begin{array}{l}\text { LIMO of } 18 / 17 \\
B C\end{array}$ & $\begin{array}{l}\text { LIMO of } 18 / 17 \\
B C\end{array}$ & $\begin{array}{l}\text { LIMO of } 18 / 17 \\
B C\end{array}$ \\
\hline $\begin{array}{l}\text { et uacatione trienni } \\
\text { data auctisque } \\
\text { praemiis }\end{array}$ & $\begin{array}{l}\text { lex Papia } \\
\text { Poppaea }\end{array}$ & $\begin{array}{l}\text { LIMO of } 18 / 17 \\
\text { BC }\end{array}$ & $\begin{array}{l}\text { LIMO of } 18 / 17 \\
B C\end{array}$ & $\begin{array}{l}\text { LIMO of } 18 / 17 \\
\text { BC }\end{array}$ \\
\hline $\begin{array}{l}\text { sic quoque } \\
\text { abolitionem eius } \\
\text { publico spectaculo } \\
\text { pertinaciter } \\
\text { postulante } \\
\text { equite, accitos } \\
\text { Germanici liberos } \\
\text { receptosque } \\
\text { partim ad } \\
\text { se partim in } \\
\text { patris gremium } \\
\text { ostentauit, } \\
\text { manu uultuque } \\
\text { significans ne } \\
\text { grauarentur imitari } \\
\text { iuuenis exemplum }\end{array}$ & $\begin{array}{l}\text { Protest in AD } \\
9 \text { against the } \\
\text { enacted lex } \\
\text { Papia Poppaea }\end{array}$ & & $\begin{array}{l}\text { Protest in AD } \\
9 \text { against the } \\
\text { draft lex Papia } \\
\text { Poppaea }\end{array}$ & $\begin{array}{l}\text { Protest in AD } \\
9 \text { against the } \\
\text { draft lex Papia } \\
\text { Poppaea }\end{array}$ \\
\hline $\begin{array}{l}\text { cumque etiam } \\
\text { inmaturitate } \\
\text { sponsarum } \\
\text { uim legis eludi } \\
\text { sentiret, tempus ... } \\
\text { sponsas habendi } \\
\text { coartauit }\end{array}$ & $\begin{array}{l}\text { 18/17 BC, shortly } \\
\text { after LIMO }\end{array}$ & $\begin{array}{l}\text { lex Papia } \\
\text { Poppaea } \\
\text { AD } 9\end{array}$ & $\begin{array}{l}18 / 17 \mathrm{BC} \\
\text { shortly after } \\
\text { LIMO }\end{array}$ & $\begin{array}{l}\text { lex Aelia } \\
\text { Sentia AD } 4 \\
\text { or lex Papia } \\
\text { Poppaea } \\
\text { AD } 9\end{array}$ \\
\hline $\begin{array}{l}\text { et matrimoniorum } \\
\text { crebra mutatione } \\
\text {... diuortiis modum } \\
\text { imposuit }\end{array}$ & $\begin{array}{l}\text { 18/17 BC, shortly } \\
\text { after LIMO }\end{array}$ & $\begin{array}{l}\text { lex Papia } \\
\text { Poppaea } \\
\text { AD } 9\end{array}$ & $\begin{array}{l}18 / 17 \mathrm{BC} \\
\text { shortly after } \\
\text { LIMO }\end{array}$ & $\begin{array}{l}\text { lex Aelia } \\
\text { Sentia AD } 4 \\
\text { or lex Papia } \\
\text { Poppaea } \\
\text { AD } 9\end{array}$ \\
\hline
\end{tabular}

\section{Abstract}

The Emperor Augustus' so-called social or moral legislation features prominently in legal and historical discussions of his principate. His biographer Suetonius concentrates into one chapter a discussion of Augustus' leges rogatae, which has never been analysed phrase by phrase by any scholar of Roman history or law since Paul Jörs in 1893. This article sets out to explain how Suetonius orders his discussion, chooses precise vocabulary, highlights key stages in the legislative programme, and does not conceal opposition to the legislation. The most controversial law, on 
which Suetonius centres his discussion, is the lex Iulia de maritandis ordinibus, key provisions of which were amended in the lex Papia Poppaea of AD 9. I argue that Suetonius comments not only on the lex Iulia de maritandis ordinibus, but also on later amendments, whether in the putative lex Aelia Sentia of AD 4 or the indisputable lex Papia Poppaea. There is, however, no reference to any abortive moral legislation of $27 \mathrm{BC}$. Suetonius presents an emperor concerned with major social issues, careful in the formulation of his laws, but also suitably responsive to societal pressure. 